\title{
THE BIRDS OF LAST MOUNTAIN LAKE AND STALWART NATIONAL WILDLIFE AREAS, SASKATCHEWAN
}

\section{BRENDA DALE, 409-2318 Arlington Avenue, Saskatoon, Saskatchewan. S7] 3L3}

Last Mountain Lake is renowned as a tremendous staging area for birds migrating along the Mississippi and Central Flyways. This lake hosts hundreds of thousands of geese, ducks, swans and cranes, and multitudes of the less conspicuous shorebirds. Birds of prey and songbirds migrate through this region in lesser numbers. This paper presents current information on the status of birds at the northern end of Last Mountain Lake, a history of birding expeditions, a summary of the best birdwatching areas and a breakdown of avian activity by season.

\section{The birds}

The seasonal list for Last Mountain Lake National Wildlife Area (NWA) and nearby Stalwart NWA is appended to this note. It differs slightly from the checklist released earlier this year due to the addition of a breeding species - the Merlin - and the upgrading in status of several species. ${ }^{7}$ A total of 258 species has been recorded in the vicinity of the two areas (Fig. 1). Just over 200 species can be expected every year (Table 1). Of the species present annually 89 are water and marsh birds. Twelve of 15 accidental species and 9 of 41 occasional species are water-oriented birds.

Of the one hundred species which have bred in or near the area in recent years, five are listed by the Committee on the Status of Endangered Wildlife in Canada (COSEWIC), the Caspian Tern as rare, the Ferruginous Hawk, Burrowing Owl and Loggerhead Shrike as threatened and the Piping Plover as endangered. Four species, Yellow Rail, Great Blue Heron,
Common Nighthawk and Greater PrairieChicken, nested in the past but are no longer found breeding in this area. The prairie-chicken has been extirpated - the most recent record is a specimen collected 25 October, 1940 by the Saskatchewan Museum of Natural History (SMNH). American Kestrel, Yellow Rail, Common Nighthawk, Least Flycatcher, Warbling Vireo and Lark Sparrow, all present throughout the summer, are thought to breed but the evidence of eggs or young is lacking.

The 1977 version of the Last Mountain Lake Checklist had 216 species of which 91 were breeding. 6 The increase of 42 species includes old records for six species. Clark's Grebe, formerly a race of the Western Grebe, is now a species. ${ }^{3}$ Wayne Harris reported seeing Clark's Grebe among Western Grebes at Last Mountain Lake in $1986 . .^{5}$ Ten species were added because the area covered by the new checklist includes Stalwart NWA, the lake south to Liberty, and the farmland and towns near the lake. Other additional species, breeding records and date extensions are a result of additional reports of observations. Eleven of the new species are considered accidental. For some species, such as the egrets, White-faced Ibis, Cinnamon Teal and Orchard Oriole, their addition to the list or upgrading in status reflects a real extension of their ranges.

\section{Bird studies}

Accurate information on the species and numbers of birds at Last Mountain Lake prior to 1960 is scarce. Visits by qualified 


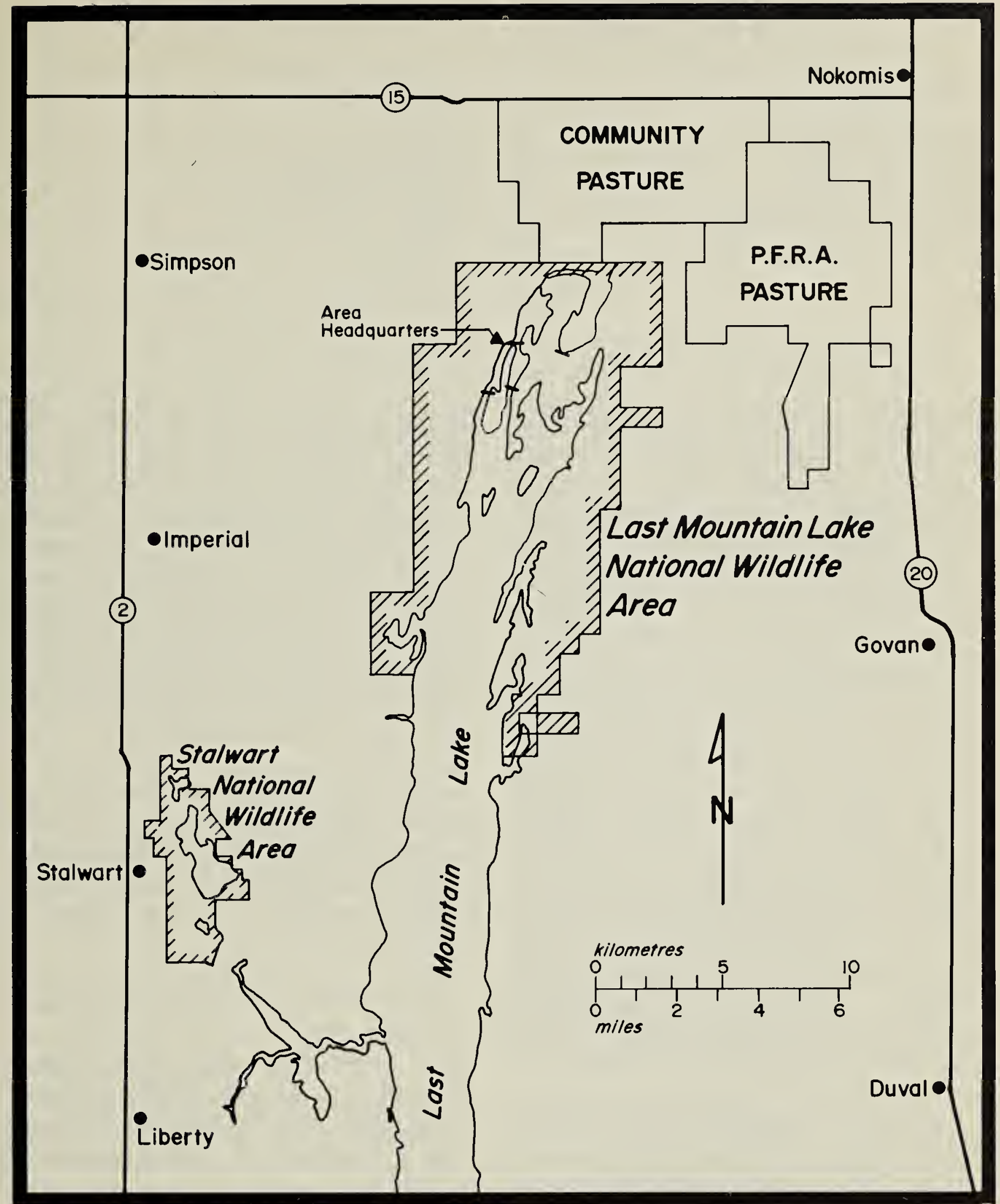

Figure 1. Last Mountain Lake - Stalwart area covered by C.W.S. bird checklist

observers were intermittent and usually brief; not all visitors kept records.

One of the first and most publicized visits was that of John Macoun and his Geological Survey of Canada party. They camped at the head of the lake during the first week of July $1879 .{ }^{17}$ Unfortunately, Macoun rarely kept bird records in his daily diary and many specimens were poorly prepared and have not survived (W. Waiser, pers. comm.). One of the few remaining records is of a Red Phalarope (one of only four records for the province). ${ }^{18}$

H. Hedley Mitchell of SMNH spent some time studying the bird life of Last 
Annual Species

Resident (Breeding)

Migrant (Breeding)

Migrant

Summer (Non-breeding)

Winter

TOTAL
Irregular Species

8 Extirpated

90 Migrant (Breeding)

72 Migrant and Summer

19 Winter

12 Accidental
1

2

32

7

15

57

Mountain Lake, but his description of the avifauna of Saskatchewan is not very helpful in determining what he saw at specific places. ${ }^{119}$ The provincial museum has specimens of 120 species collected at the north end of Last Mountain Lake. Judging from specimen dates, collecting expeditions by the museum or affiliated collectors occurred in the 20s, 30s, 40s and 50s. There are also a few specimens from as early as 1913 and from the 60s to the present. Museum specimens provide the only records for the area of such species as the Turkey Vulture (5 October 1955), Yellow-bellied Flycatcher (27 May 1930), Alder (Traill's) Flycatcher (22 and 26 May 1930), and Rufous-sided Towhee (27 May 1924). There are also specimens of Oldsquaw, Parasitic Jaeger, Greater PrairieChicken, Western Wood-Pewee, Dickcissel and Smith's Longspur which have few other records for the lake.

Captain W.C. Huggins' monthly reports to J.B. Harkin in Ottawa for the period 1923 to 1931 , usually noted the first and last dates of the obvious and more economically important bird species. ${ }^{5} \mathrm{His}$ reports were not always very specific (e.g."ducks going north)."

Reuben Lloyd and his son, Albert, of Davidson were active banders who ringed 246 Double-crested Cormorants at Last Mountain Lake in the period 1923-28. ${ }^{14}$ Albert Lloyd and George M. Sutton were part of the 1932 Carnegie Museum col-

lecting expedition led by W.E. Clyde Todd. They spent 22 May to 7 June and 12 to 20 June 1932 at the head of Last Mountain Lake. A total of 477 specimens of 83 species was collected. The summary of their sightings was published some years later. ${ }^{22}$ This paper and the Carnegie Museum's Last Mountain Lake collection provide the first comprehensive coverage of the avifauna of Last Mountain Lake with 120 species seen or collected.

Fred Bard of the SMNH banded birds (mainly waterfowl, pelicans and cormorants) at Last Mountain Lake in 1934, 36-40, 48 and $49 .{ }^{15} 16 \mathrm{C}$. Stuart Houston banded pelicans and cormorants in $1954 .^{13}$

Brief visits by B.H. Segre (1913), R.M. Anderson (1917), P.A. Taverner and Hoyes Lloyd (1920), C.G. Harrold (1922 and 28), J.A. Munro (1927), J.Dewey Soper (1936 and 1947) and D.A. Munro (1947) resulted in some additional records.

Visits by Canadian Wildlife Service (CWS) personnel began in 1960 and thereafter the quantity of records increased. A study of Sandhill Cranes was conducted from 1961-63.21 The first of two resident managers was assigned there in 1968. John Hatfield (1968-1973) and Clint Jorgenson (1973-) have recorded arrivals and departures of many migratory birds (mainly waterfowl and colonial 
nesting species). ${ }^{5}$ Stuart Houston began an annual banding program of Great Horned Owls and hawks in the area in 1966. Gary Anweiler spent the spring, summer and fall of 1969 studying the natural history of the area. He kept extensive notes with records for 186 bird species. ${ }^{4}$ Ken Lumbis and Mike Gollop studied Sandhill Crane migration in and around the sanctuary in 1975 and 1976, respectively. They kept records of all other species seen. ${ }^{5}$ Wayne Harris has organized and compiled Christmas Bird Counts at the north end of the lake for the last 14 years. His other visits to Last Mountain Lake throughout the year have provided records. The author studied grassland passerines at Last Mountain Lake in 1980-81 and kept a daily log of all species seen in the Wildlife Area (171 species). ${ }^{9}$ Twelve visits to Stalwart NWA in 1983 resulted in records for 103 species. ${ }^{10}$ Mark Colwell studied shorebirds (mainly Wilson's Phalarope) in spring and early summer from 1982-87.8 A CWS study on the effects of fire on grassland vegetation and birds ran from 1982 to $1987 .{ }^{11}$ CWS projects monitored fall waterfowl and crane numbers and feeding patterns from 1982 to 1986 . Short visits by CWS personnel (principally J.B. Gollop, A.R. Smith and P.S. Taylor) and local and international birdwatchers have produced other records.

\section{Where to find birds}

The National Wildlife Areas are primarily places for wildlife. NWA regulations provide protection for wildlife and the habitat that sustains it. Many old trails are closed and access is restricted to foot traffic. Some areas are off-limits for portions of the year, for example the lure crops during fall migration and the vicinity of nesting colonies in spring and early summer. Within these limitations there are still many opportunities to observe birds and other wildlife in the NWAs. To locate points referred to in the text refer to Figure 2.
May, September and October are peak months for migrant waterbirds on the lake. Last Mountain Regional Park on the east side and Imperial or Etter's Beach $(7 \mathrm{~km}$ south of NWA) on the west are good vantage points. Boat launching is permitted at the Regional Park and Etter's Beach but no one should approach the islands or Perry's Point where colonial nesting occurs.

The Auto Tape Tour beginning at the Information Centre provides opportunities to see almost every type of habitat ocurring at Last Mountain Lake. The road travels past five basins created by Ducks Unlimited dams at the northern extremities of the lake. These basins contain deep water, marsh, wet meadow and bare shoreline which provide food, shelter, and loafing sites for many migrant and breeding species. A Viewing Tower near the basin east of the Information Centre provides an excellent view of several of the basins. The Wetland Nature Trail starts and ends at the Picnic Area. Ducks Unlimited recently constructed two dykes in Basin A. These structures give greater control over the water level in the basin and provide extra shoreline for migrating shorebirds and loafing ducks. Interspersed with the basins are many types of grassland habitat which support upland game and shorebirds as well as songbirds. Because of the variety of grassy habitats it is possible, by moving from marsh into upland, to encounter Sharp-tailed, Le Conte's, Savannah, Baird's, Clay-colored and Vesper Sparrows. Grasshopper Sparrows also occur in a very few locales. A $2 \mathrm{~km}$ long Grassland Nature Trail is located on the tour road.

There are very few treed areas in these NWAs. Migrating passerines concentrate in the Regional Park, Picnic Area, shelterbelts and farmsteads.

Stalwart NWA, just east of Highway No.2, has about 1500 ha of marsh and 


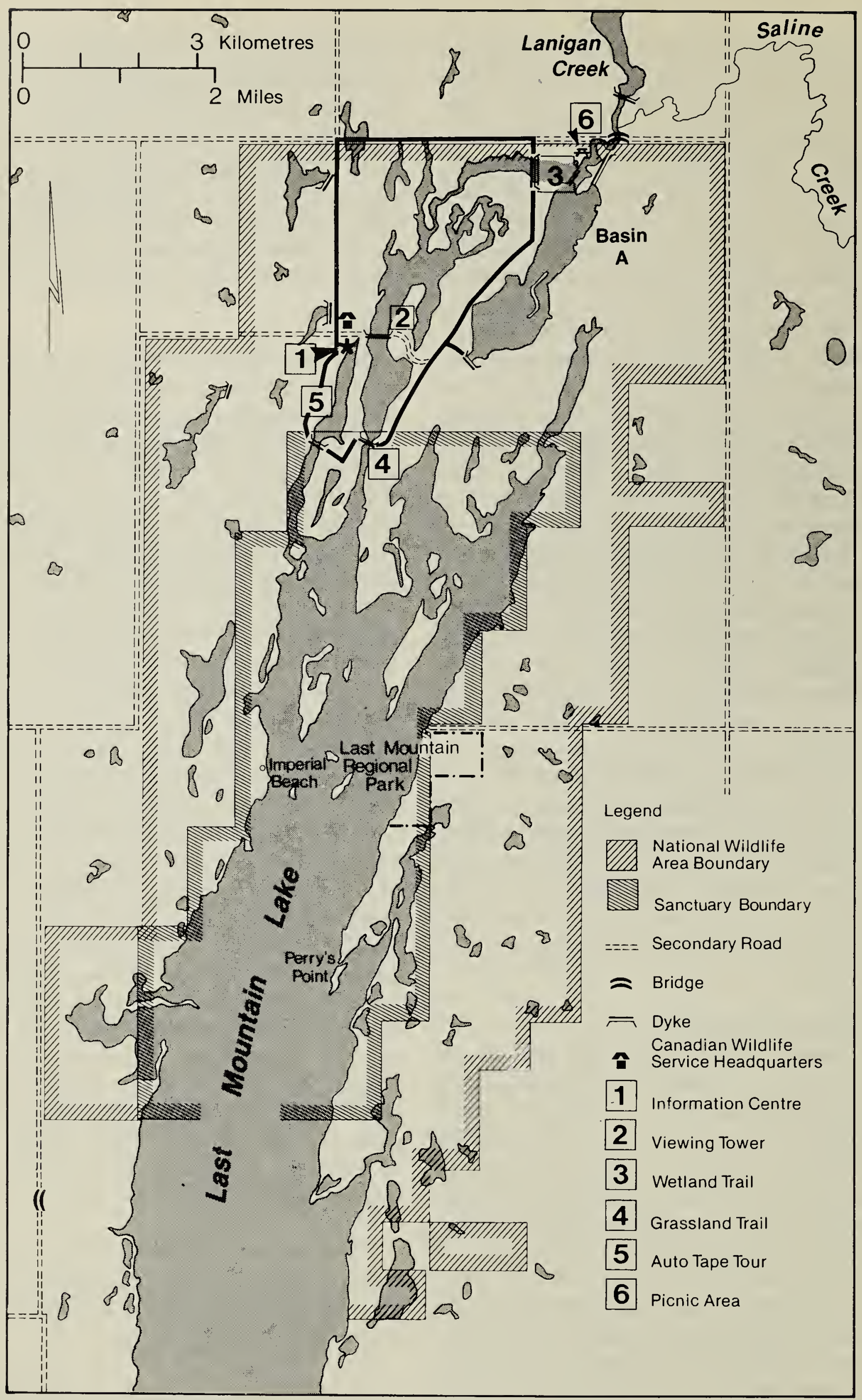

Figure 2. Points of interest Last Mountain Lake National Wildlife Area and Migratory Bird Sanctuary 


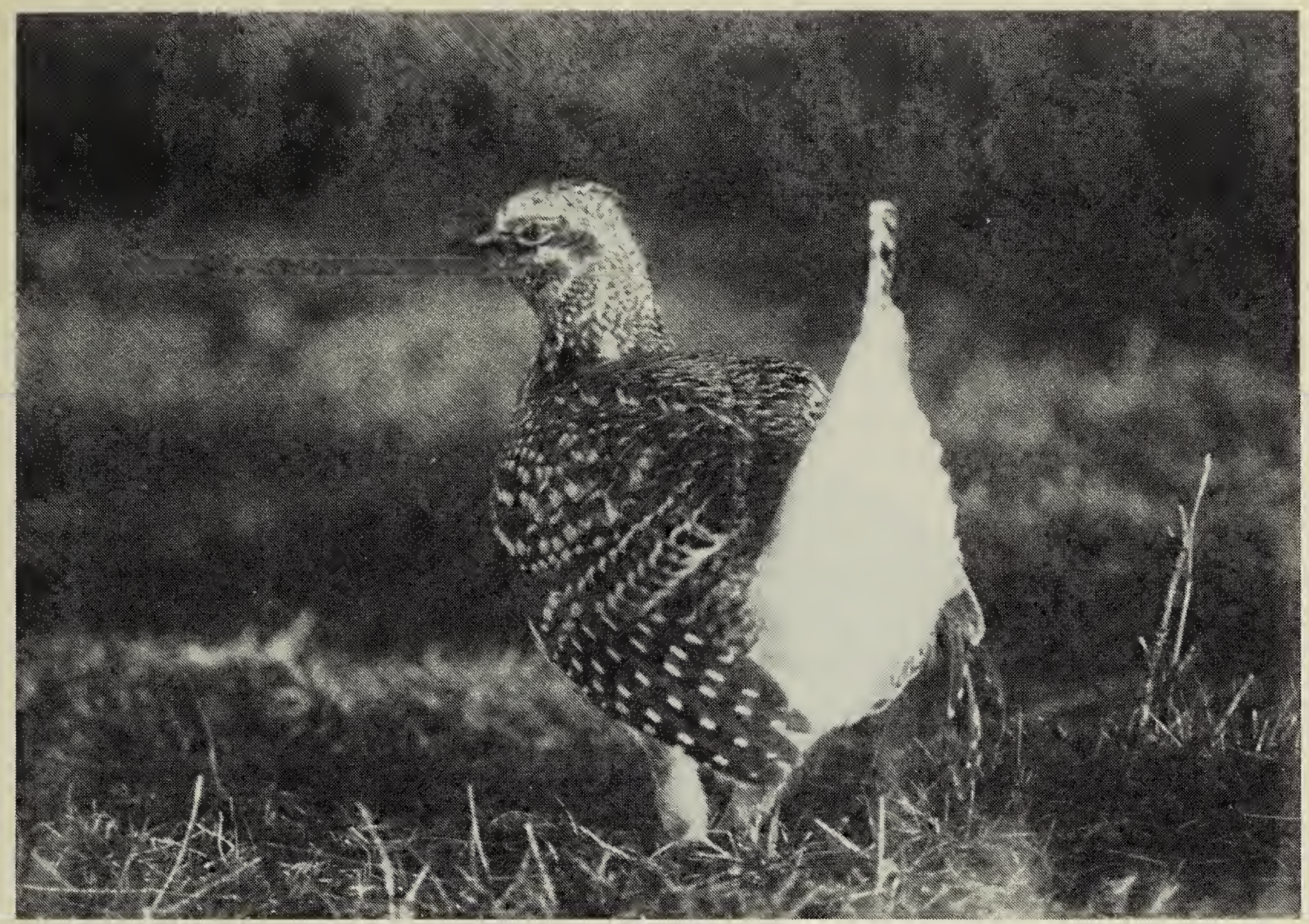

Sharp-tailed Grouse

G.W. Beyersbergen

associated uplands in sight of or within easy walking distance of grid roads. The marshes support breeding and migrating grebes, herons, waterfowl, rails, shorebirds and songbirds. Burrowing Owls have been found breeding in several places on and near the NWA.

The number of species that can be seen in the area fluctuates with the seasons. Table 2 gives the seasonal variation in numbers of species.

\section{Spring (March through May)}

Spring migration results in large concentrations of and a great diversity of birds.
Great Horned Owls are attending nests by the end of March and Sharp-tailed Grouse begin their ritual courtship dancing (there are about 30 leks in the two areas). A few Snowy Owls usually linger on the lake ice until spring breakup. The first crows, meadowlarks and harriers arrive in March or early April. April and May bring at least 170 additional species to the north end of Last Mountain Lake. The 8 resident species and members of about 90 other species will breed while others of their kind fly farther north with the strictly migrant species.

Canada Geese and Mallards begin ar-

\section{Table 2. SUMMARY OF SPECIES ABUNDANCE BY SEASON}

Abundance

Abundant

Common

Uncommon

Rare

Occasional
Spring

8

81

74

16

30
Summer

2

68

50

25

27
Fall

Winter

11
56
83
31
24




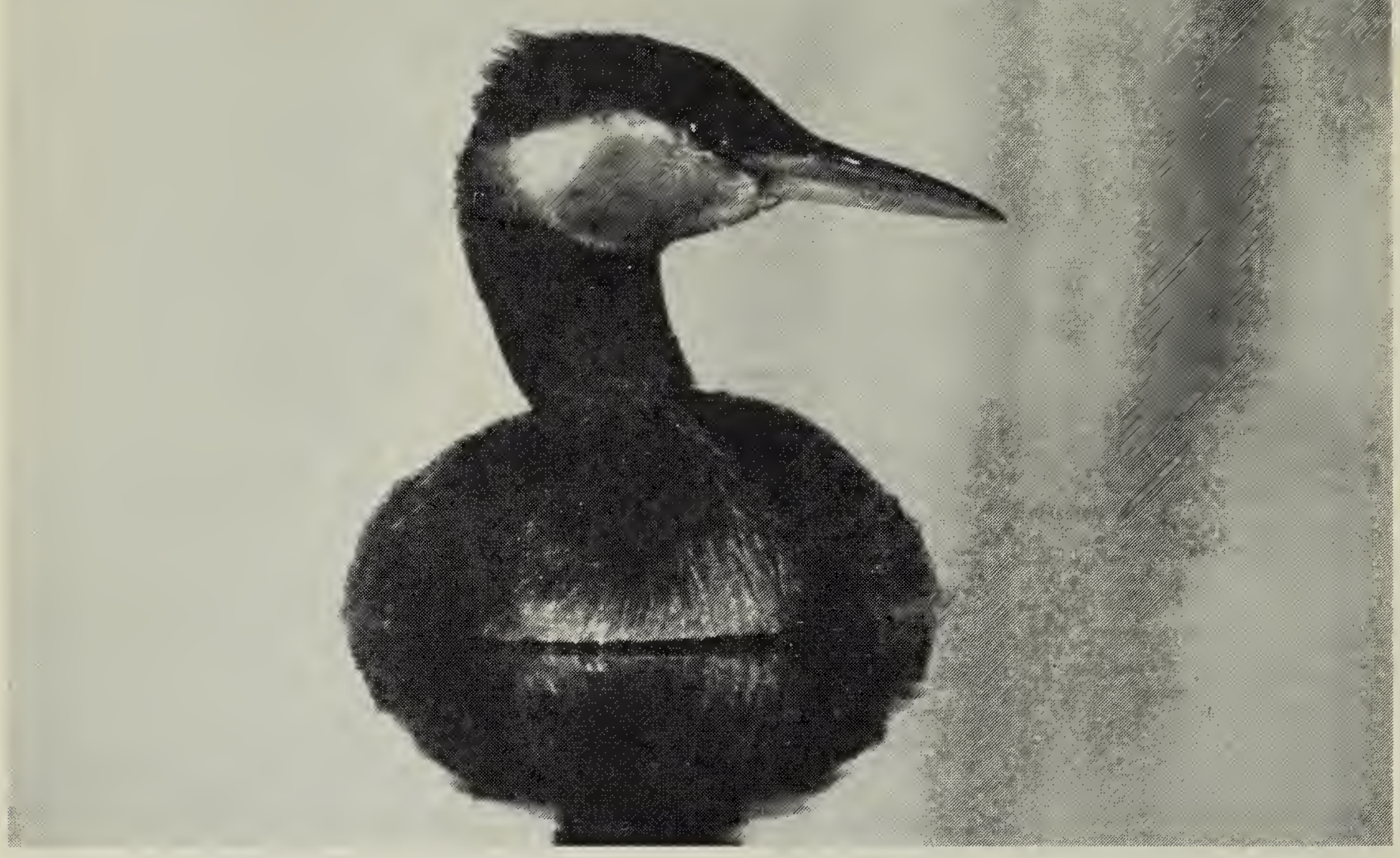

riving before the ice is gone from the lake or basins. Species and numbers increase until at least 23 species of waterfowl numbering in the hundreds of thousands arrive. Several hundred pairs of Canada Geese and members of 12 duck species remain to nest while the swans, most geese and a large number of ducks move farther north.

The break up of ice is followed by the arrival of many other water birds: Common Loon, grebes (6 species), pelicans, cormorants, herons, coots, rails, shorebirds, gulls and terns. Great, Snowy, and Cattle egrets and White-faced Ibis have been appearing in Saskatchewan and at Last Mountain Lake with greater frequency in the last decade. The Great Egret has become almost an annual visitor to the lake.

The breeding shorebirds (Piping Plover, Killdeer, American Avocet, Willet, Spotted Sandpiper, Upland Sandpiper, Marbled Godwit, Common Snipe and
Wilson's Phalarope) arrive from mid-April through early May. The 21 species of migrant shorebirds begin arriving around the end of April and use a variety of habitats: pastures, marshes, mudflats, temporary wetlands and sandy or rocky shores.

Migrating Sandhill Cranes provide a spectacle worth seeing. Thousands of cranes pass through the area on their way north. During the peak migration, from mid-April through early May, sighting several thousand feeding and courting cranes in a stubble field is not unusual. The endangered Whooping Crane makes very few spring appearances at Last Mountain Lake.

Osprey, eagles, hawks and falcons remain in the area for varying lengths of time. Only Northern Harriers, Swainson's and Red-tailed Hawks are common. Among the less frequently observed raptors are the Cooper's Hawk and Peregrine Falcon considered rare and endangered, 
respectively, by COSEWIC.

Flocks of Lapland Longspurs appear in the open fields early in April. Most passerines do not begin to arrive until May. Because of the scarcity of trees at Last Mountain Lake it is not on an important route for migrant flycatchers, vireos and warblers. The only regularly occurring spring flycatchers are the three that breed or are suspected to breed at the lake. There are spring records for just 14 warbler species, only 10 species occurring with any regularity. Most thrushes and sparrows can be observed in the area during migration.

\section{Summer (June through August)}

Summer is a relatively quiet season. During the heat of the summer birds are less numerous or obvious than during migration. In June breeding species are still singing and displaying; young grebes, waterfowl, shorebirds and grouse make their appearance. Many passerines are feeding young and by the end of June song begins to diminish in frequency. Female Wilson's Phalaropes complete their clutches and depart, leaving the males to hatch and raise the young. The last migrating shorebirds depart for the north about the time the yellowlegs and dowitchers begin to move south again. As fall approaches numbers reach impressive figures such as 15 thousand Red-necked Phalaropes reported in late August 1973. The colonial nesting species (Doublecrested Cormorants, Ring-billed and California gulls, Common and the rare Caspian terns) raise their young on islands in the lake. The American White Pelican has recently been delisted by COSEWIC because of its improved continental breeding success. At Last Mountain Lake the pelicans' breeding record is still poor with only three successful breeding seasons (1972, 1984 and 1987) since 1954. ${ }^{12} 20$ Ducks congregate to moult. Sandhill Cranes begin arriving from the north early in August.

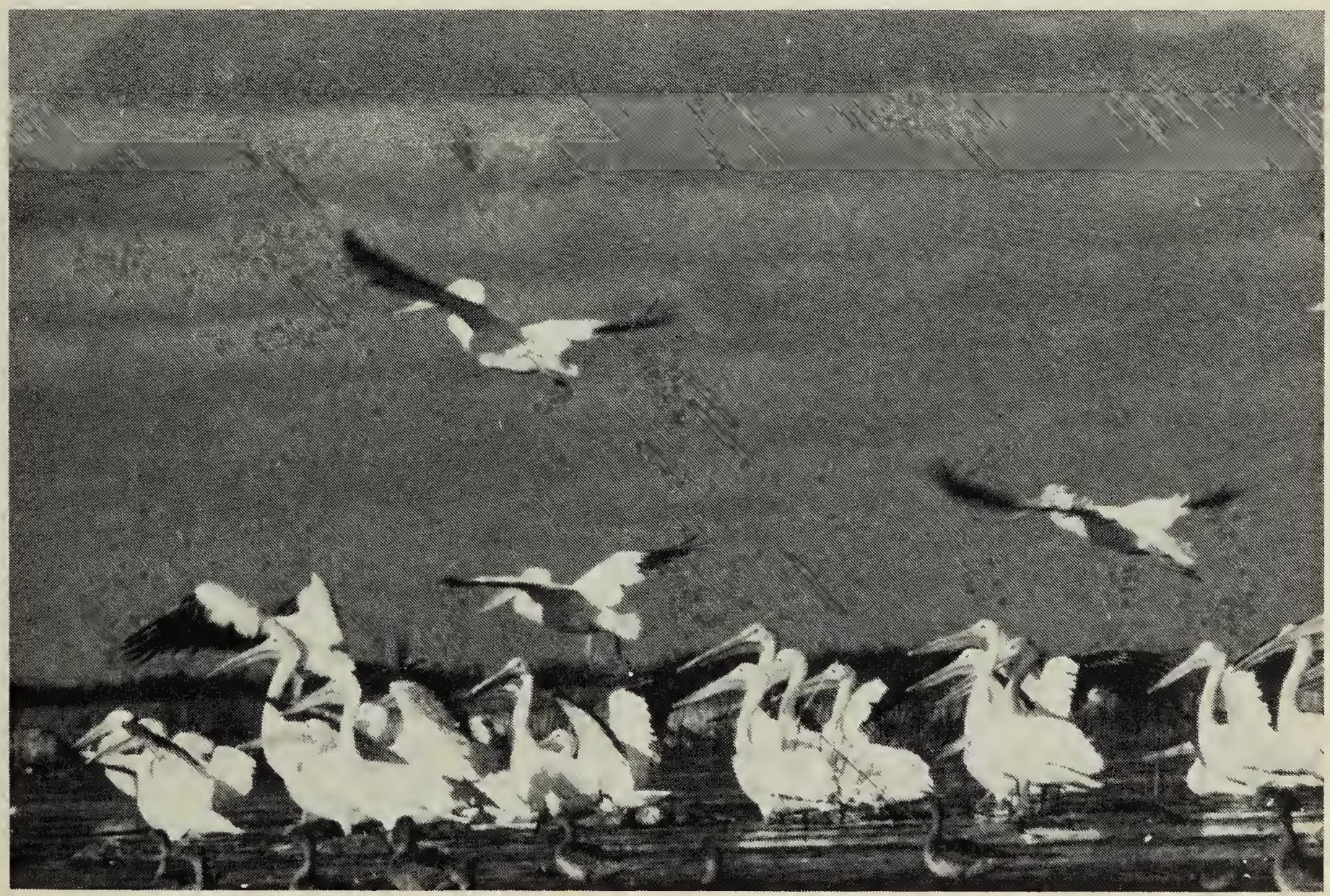

American White Pelican

G.W. Beyersbergen 


\section{Fall (September through November)}

This season is marked at Last Mountain Lake with spectacular concentrations of waterfowl and cranes, a great diversity of other migrants, plus the possibility of seeing rare and occasional species such as jaegers or endangered birds like the Peregrine Falcon or Whooping Crane. The timing of migration is largely determined by the severity of the weather. At the peak there will be hundreds of thousands of swans, geese, ducks and cranes (103 thousand geese 26 September 1984; 60 thousand Mallards 24 September 1986; 30 40 thousand Sandhill Cranes reported several times). Tremendous dawn and dusk flights take place accompanied by the all-pervasive voices of waterfowl and cranes. Some lure crops and grainfields will be blanketed with dark and white bodies; rafts of diving ducks will cover the deeper water of the basins or float on the main lake. Migrants swell the numbers of grebes and cormorants into the tens of thousands. As many as 16 species of raptors may pass southward but, as in the spring, only harriers and some buteos are common. Vireos, drab fall warblers and an assemblage of sparrows use the shelterbelts, farmsteads, and the trees and bushes bordering the lake. Grouse, partridge, pipits, sparrows and meadowlarks flush from grasslands and hayfields.

\section{Winter (December through February)}

This is a quiet season at Last Mountain Lake. The few resident species (Gray Partridge, Sharp-tailed Grouse, Rock Dove, Great Horned and Short-eared owls, Black-billed Magpie, European Starling and House Sparrow) are mainly concentrated in farmsteads. A few Northern Shrikes spend the winter months this far north, hunting from shelterbelts and farmsteads. Forest birds (woodpeckers, chickadees, grosbeaks and redpolls) appear in the farmsteads. Snowy Owls and Snow Buntings arrive from arctic Canada in the fall to winter in open fields. A few raptors such as Northern Goshawk, Rough-legged Hawk and Golden Eagle are seen rarely, hunting in the area.

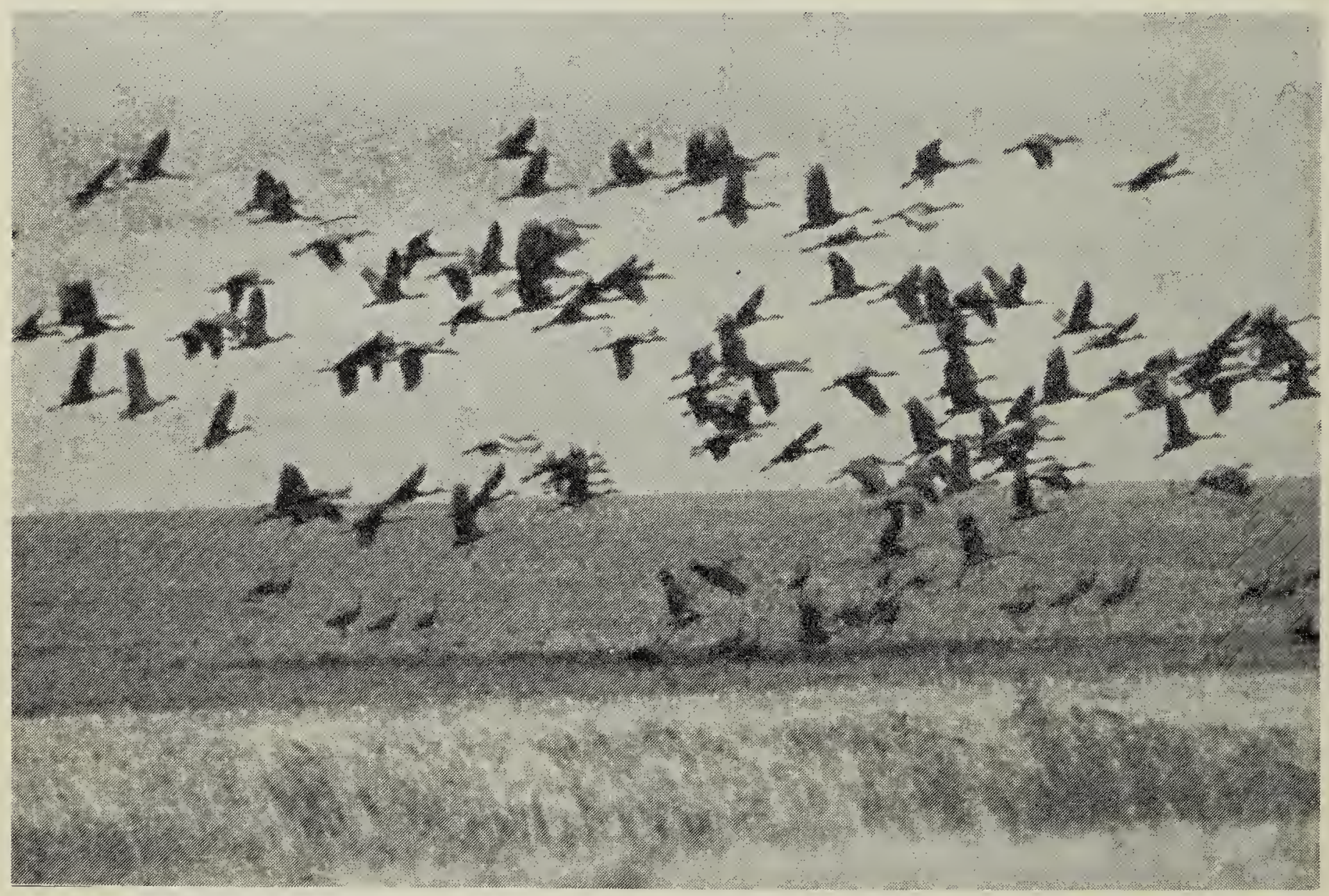


The end of the winter season is marked by the reappearance of the Horned Lark (a few may winter here) which begins to migrate early and may reach peak numbers before the end of February.

\section{The Future}

The Last Mountain Lake and Stalwart National Wildlife Areas, two islands of protected, diverse wetland and grassland habitat, will continue to attract large and diverse bird populations. With time observations will lead to some changes in status and seasonal occurrence and the addition of species to the list. Many of the species currently considered as occasional may use Last Mountain Lake on an annual basis in low numbers and go undetected because of the low intensity of birdwatching. Reports of bird observations (especially if they relate to the status or seasonal occurrence of a species) would be appreciated. They can be sent to the Area Manager or the Habitat Biologist at the Canadian Wildlife Service.

\section{Acknowledgements}

The Saskatchewan Museum of Natural History, the National Museum of Natural Sciences and the Carnegie Museum made records available. I am grateful to Keith Roney, Paul James, Henri Ouellet and Scott Wood of the aforementioned museums for their aid. I wish to thank the many individuals who shared their Last Mountain Lake bird records with the Canadian Wildlife Service. I thank Bernard Gollop and Philip Taylor for their comments.

1 ANDERSON, R.M. 1918. Letter to J.A. Munro. CWS files.

2 AMERICAN ORNITHOLOGISTS' UNION 1983. Check-list of North American birds. 6th Edition. Am. Ornithologists' Union. Lawrence, Kansas. 877 pp.

3 AMERICAN ORNITHOLOGISTS' UNION 1985. Thirty-fifth supplement to the American Ornithologists' Union Check-list of North American birds. Auk 102:680-686.

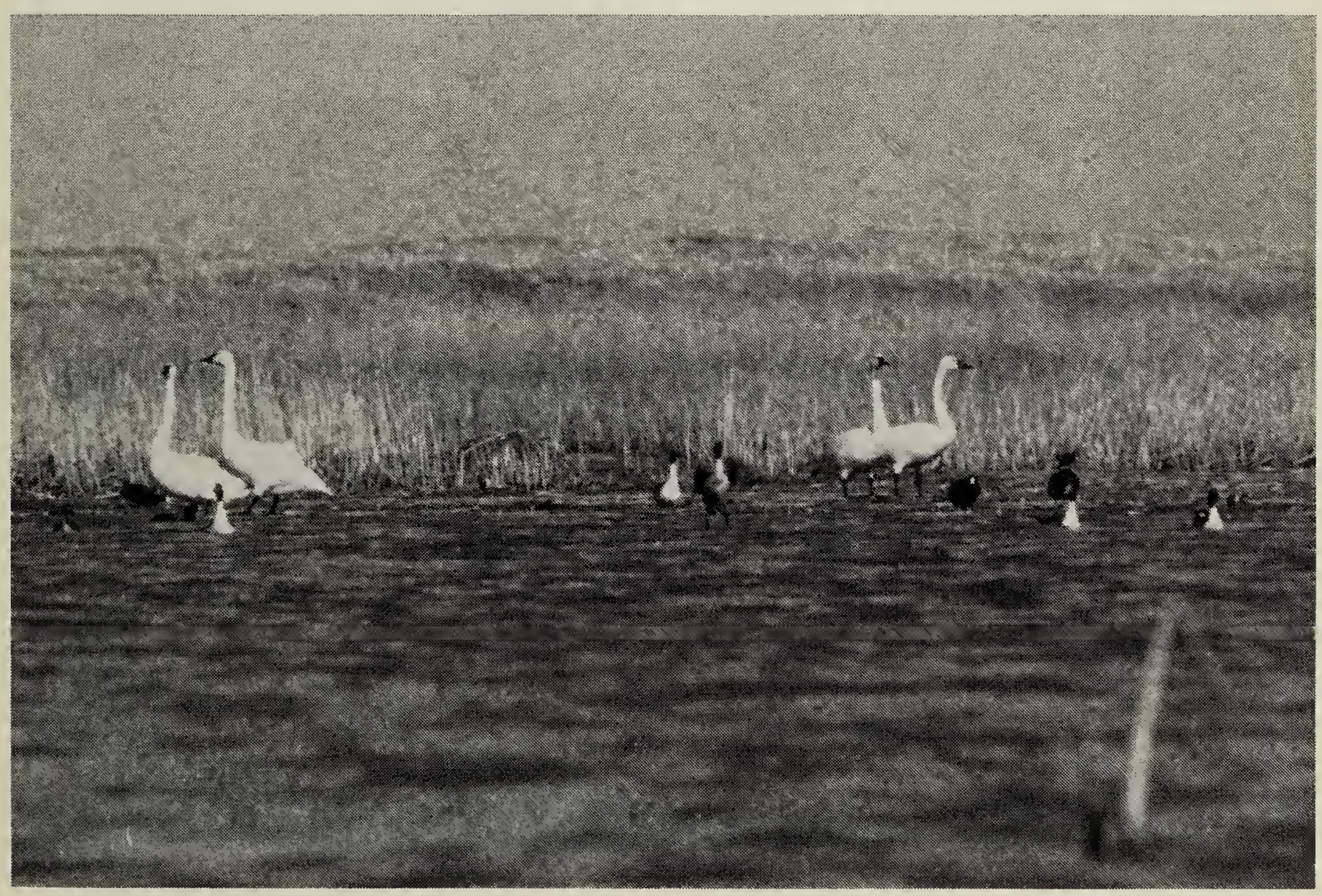

Tundra Swans

G.W. Beyersbergen 
4 ANWEILER, G.G. 1970. The birds of the Last Mountain Lake Wildlife Area, Saskatchewan. Blue Jay 28(2):74-83.

5 CANADIAN WILDLIFE SERVICE Historic files. Saskatoon.

6 CANADIAN WILDLIFE SERVICE 1977. Bird check-list. Last Mountain Lake Wildlife Management Unit and vicinity, Saskatchewan. 8 panel brochure.

7 CANADIAN WILDLIFE SERVICE 1987. Last Mountain Lake and Stalwart National Wildlife Areas bird checklist. 14 panel brochure. CW66-85/1987E.

8 COLWELL, M.A. 1986. Shorebird Management Plan, Last Mountain Lake Wildlife Management Unit. Unpub. report. C.W.S., Saskatoon. 29 pp.

9 DALE, B.C. 1982. A summary of bird observations on the Last Mountain Lake Wildlife Management Unit, Saskatchewan for 1980 and 1981. Unpubl. report, Habitat Mgmt. Section, C.W.S., Saskatoon. 32 pp.

10 DALE, B.C. 1984. 1983 Observations at Stalwart National Wildlife Area, Saskatchewan. Unpubl. report, Habitat Mgmt. Section, C.W.S., Saskatoon. 17 pp.

11 DRIVER, E.A. 1987. Fire on the Last Mountain Lake Grasslands. Blue Jay 45(3):

12 HATFIELD, J.P. 1973. Pelicans return to Last Mountain Lake. Blue Jay 31(2):98.
13 HOUSTON, C.S. 1962. Hazards faced by colonial birds. Blue Jay 20(2):74-77.

14 HOUSTON, C.S. 1969. Saskatchewan bird banders: Reuben and A.C. Lloyd of Davidson. Blue Jay 27(1):24-27.

15 HOUSTON, C.S. 1970. Saskatchewan bird banders: Fred G. Bard. Blue Jay 28(3):150-156.

16 HOUSTON, C.S. 1971. Recent Saskatchewan banding of the Double-crested Cormorant. Blue Jay 29(2):74-79.

17 MACOUN, J. 1979. Autobiography of John Macoun, Canadian Explorer and Naturalist 1831-1920. 2nd Edition. Ottawa Field-Nat. Club. Ottawa.

18 MACOUN, J. and J.M. MACOUN. 1909. Catalogue of Canadian Birds. Queen's Printer. 761 pp.

19 MITCHELI., H.H. 1924. Birds of Saskatchewan. Can. Field-Nat. 38(6):101-118.

20 NERNBERG, D. 1985. Pelicans Nesting at Last Mountain Lake. Blue Jay 43(1):59-60.

21 STEPHEN, W.D. 1967. Bionomics of the Sandhill Crane. C.W.S. Report Series, No. 2. Queen's Printer, Ottawa. 48 pp.

22 TODD, W.E.C. 1947. Notes on the Birds of Southern Saskatchewan. Annals of the Carnegie Museum 30:383-421.

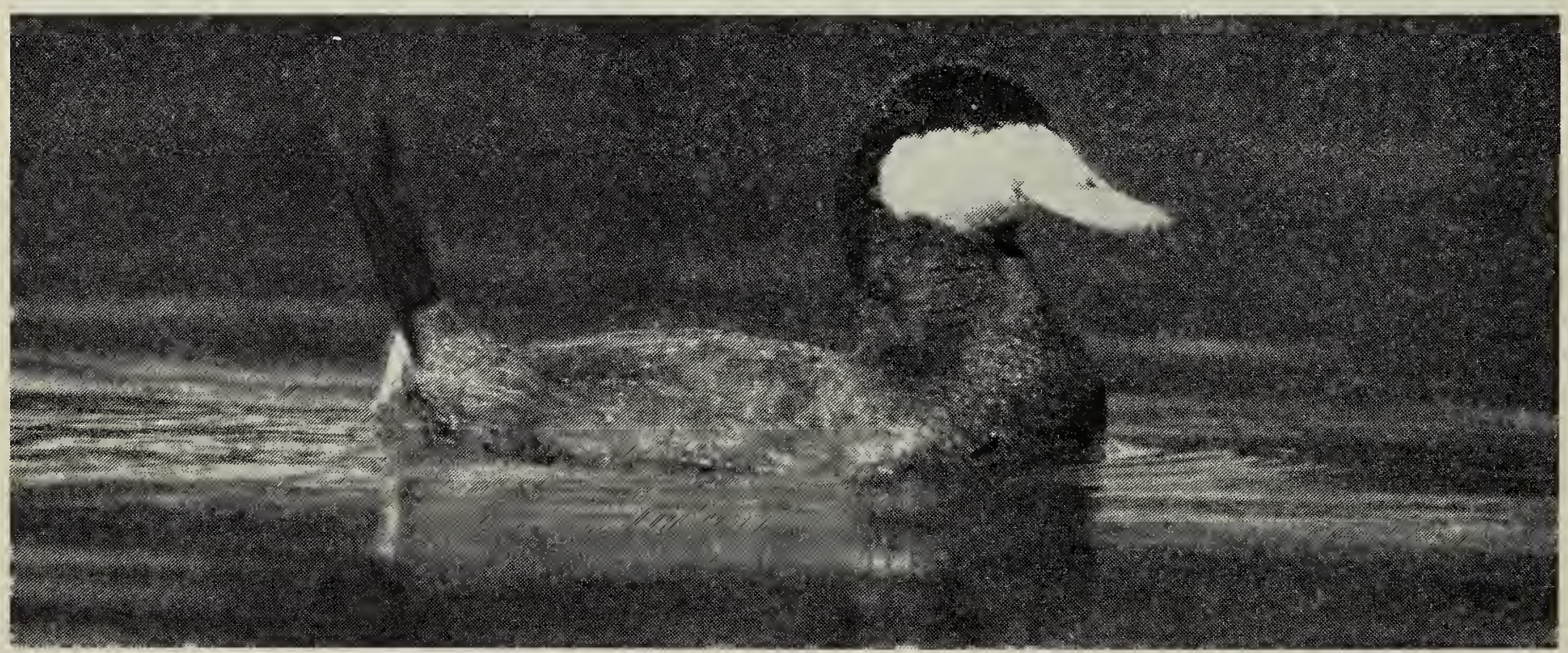


The common names and sequence of species of this list are based on the 6th edition and 35th supplement of the American Ornithologists' Union "Check-list of North American birds." 23 Some common names will differ from those used in field guides published prior to 1983.

Terms and symbols in the checklist are as follows:

\section{Seasons}

Sp Spring.......................................

Su Summer.............June-August

F Fall......... September-November

W Winter..........December-February

\section{Breeding status - B}

* - Indicates confirmed breeding

? - Present throughout summer but nest or young not seen

\section{Abundance}

A - Abundant: Seen on all visits to the preferred habitat within the proper season. Often occurs in large numbers.

C - Common: Seen on a majority of visits to the preferred habitat within the proper season. Numbers may vary considerably.

U - Uncommon: Seen on some visits to preferred habitat in the proper season. Present annually, but occurs in low numbers.

$\mathbf{R}$ - Rare: Expected every year, but in very low numbers at varying locations and may be difficult to find.

O - Occasional: Not expected every year.

Accidental: Last Mountain Lake is well outside its normal range. Not expected to occur again.

Extirpated: Species has been eliminated from this portion of its range.

\begin{tabular}{|c|c|}
\hline \multirow{2}{*}{\multicolumn{2}{|c|}{$B S p S u F$ И }} \\
\hline & \\
\hline Pacific Loon & Accidental \\
\hline Common Loon & $U R U$ \\
\hline Grebes & \\
\hline Pied-billed Grebe & $* \mathrm{C} C \mathrm{C}$ \\
\hline Horned Grebe & $* \quad \cup \cup$ \\
\hline Red-necked Grebe & * $\cup \cup \cup$ \\
\hline Eared Grebe & $* \mathrm{C} \quad \mathrm{C}$ \\
\hline Western Grebe & * C C C \\
\hline Clark's Grebe & * $\mathrm{R} \quad \mathrm{R} \quad \mathrm{R}$ \\
\hline
\end{tabular}

Pelicans and Cormorants American White Pelican * C C C -
Group Species

Double-crested Cormorant

Herons and Ibises

American Bittern

Great Blue Heron

Great Egret

Snowy Egret

Little Blue Heron

Cattle Egret

Black-crowned

Night-Heron

White-faced Ibis

\section{Swans and Geese}

Tundra Swan

Trumpeter Swan

Greater White-fronted Goose

Snow Goose (includes Blue)

Ross' Goose

Brant

Canada Goose

\section{Ducks}

Wood Duck

Green-winged Teal

American Black Duck

Mallard

Northern Pintail

Blue-winged Teal

Cinnamon Teal

Northern Shoveler

Gadwall

American Wigeon

Canvasback

Redhead

Ring-necked Duck

Greater Scaup

Lesser Scaup

Oldsquaw

Surf Scoter

White-winged Scoter

Common Goldeneye

Barrow's Goldeneye

Bufflehead

Hooded Merganser

Common Merganser

Red-breasted Merganser

Ruddy Duck

Hawks, Vultures and Allies

Turkey Vulture

Osprey

Bald Eagle
$B$ Sp Su F W

* C C A -

* C C C -

$\mathrm{U} \cup \mathrm{U}$ -

$\mathrm{O} \mathrm{O}-$

$\mathrm{O} \mathrm{O}$

Accidental

$\mathrm{O} \mathrm{O}$ - -

* C C C -

$\mathrm{O} \mathrm{O}-$

$\mathrm{CO}$ C -

Accidental

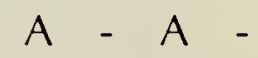

$A-A$ -

$U-U$ -

Accidental

* A C A

- $\mathrm{OO}$ -

U U U -

O R R -

* A C A O

* C C C -

* C C C -

$\mathrm{R} O \mathrm{O}$ -

* C C C -

* C C C -

* C C C -

* C U C -

* $\mathrm{C} \cup \mathrm{C}$ -

U R U -

$O-$ -

* A C A -

$\mathrm{O}-\mathrm{O}$

Accidental

* $U \cup U$ -

U O U -

Accidental

U U U -

$\mathrm{R} O \mathrm{R}$ -

U O U -

$U-U$ -

C C A -

Accidental

R O R

$U-U$ 
Group Species

Northern Harrier

Sharp-shinned Hawk

Cooper's Hawk

Northern Goshawk

Swainson's Hawk

Red-tailed Hawk

Ferruginous Hawk

Rough-legged Hawk

Golden Eagle

\section{Falcons}

American Kestrel
Merlin
Peregrine Falcon
Gyrfalcon
Prairie Falcon

\section{Grouse}

Gray Partridge

Ring-necked Pheasant

Ruffed Grouse

Greater Prairie-Chicken

Sharp-tailed Grouse

Rails and Coots

Yellow Rail

Virginia Rail

Sora

American Coot

\section{Cranes}

Sandhill Crane

Whooping Crane

\section{Plovers}

Black-bellied Plover

Lesser Golden-Plover

Semipalmated Plover

Piping Plover

Killdeer

\section{Avocets}

American Avocet

\section{Sandpipers and Allies}

Greater Yellowlegs

Lesser Yellowlegs

Solitary Sandpiper

Willet

Spotted Sandpiper

Upland Sandpiper

Whimbrel

Long-billed Curlew

Hudsonian Godwit

Marbled Godwit

Ruddy Turnstone

Red Knot

Sanderling

Semipalmated Sandpiper

Least Sandpiper

White-rumped Sandpiper

Baird's Sandpiper
$B$ Sp Su F W

* C C C -

$U-U-$

$U-U-$

$\mathrm{O}-\mathrm{O} R$

* C C C -

* C R C -

* $\mathrm{R} R \mathrm{R}$ -

$U-U R$

$R$ - R R

? $U R \cup$.

* U R U .

$\mathrm{R} O \mathrm{R}$ -

- $-\mathrm{OO}$

$\mathrm{O}-\mathrm{R}$ -

* C C C C

$\mathrm{O} O \mathrm{O} \quad \mathrm{O}$

$\mathrm{O} O \mathrm{O} O$

Extirpated

* C C C C

? $U \cup R$ -

* $U U$ - -

* C C C -

* C C A -

$A \cup A$ -

$O-R$ -

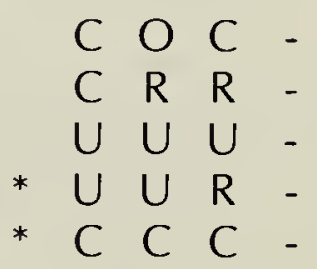

* C C C -

$U \mathrm{C}$ C -

$C \mathrm{C}$.

$R \cup R$ -

* C C C -

* U U U -

* U U - -

$\mathrm{O}-\mathrm{C}^{-}$

$\mathrm{O}--$

$U \cup U$ -

* C C C -

$\mathrm{U} U$ - -

C $\cup \mathrm{O}$ -

$c \cup \cup$ -

$C \mathrm{C} U$ -

$C \mathrm{C} U$ -

$U U$ - -

$C \cup \cup$ -
Group Species

Pectoral Sandpiper

Purple Sandpiper

Dunlin

Stilt Sandpiper

Buff-breasted Sandpiper

Short-billed Dowitcher

Long-billed Dowitcher

Common Snipe

Wilson's Phalarope

Red-necked Phalarope

Jaegers

Pomarine Jaeger

Parasitic Jaeger

Gulls

Long-tailed Jaeger

Franklin's Gull

Bonaparte's Gull

Ring-billed Gull

California Gull

Herring Gull

Thayer's Gull

Glaucous Gull

Terns

Sabine's Gull

Caspian Tern

Common Tern

Forster's Tern

\section{Doves}

Black Tern

Rock Dove

Mourning Dove

\section{Cuckoos}

\section{Owls}

Black-billed Cuckoo

Great Horned Owl

Snowy Owl

Burrowing Owl

Long-eared Owl

Short-eared Owl

Nighthawks

Common Nighthawk

Hummingbirds

Ruby-throated

Kingfishers

Hummingbird

Belted Kingfisher

Woodpeckers

Yellow-bellied

Sapsucker

Downy Woodpecker

Hairy Woodpecker

Northern Flicker

Tyrant Flycatchers

Olive-sided Flycatcher
B Sp Su FW

$C \mathrm{C} \cup$ -

Accidental

U U -

$C \mathrm{C} U$ -

$R-$ -

U U R

C C U

* UUU -

C C -

C A U -

Accidental

$\mathrm{O}-\mathrm{O}$

Accidental

* C C C

$\cup \cup \cup$

* A A A

* C CU.

U O U

Accidental

Accidental

Accidental

* U U -

* C C R .

* UU -

* C C U .

* C C C C

* C C U -

* - U R -

* $U U U U$

$U-U U$

* $\mathrm{R}$ R R -

* U U U -

* C C C R

? $\cup \cup \cup$

U R U -

$U R U$ -

$U-U-$

- OUU

- OUU

* C C C -

O 
Group Species

Western Wood-Pewee

Yellow-bellied

Flycatcher

Alder Flycatcher

Least Flycatcher

Eastern Phoebe

Say's Phoebe

Great Crested

Flycatcher

Western Kingbird

Eastern Kingbird

Larks

Horned Lark

Swallows

Purple Martin

Tree Swallow

Northern Rough-winged

Swallow

Bank Swallow

Cliff Swallow

Barn Swallow

Jays, Crows and Magpies

Gray Jay

Blue Jay

Black-billed Magpie

American Crow

Common Raven

Chickadees

Black-capped Chickadee

Nuthatches

Red-breasted Nuthatch

Creepers

Brown Creeper

Wrens

Rock Wren

House Wren

Sedge Wren

Marsh Wren

Kinglets

Golden-crowned

Kinglet

Ruby-crowned Kinglet

Thrushes

Mountain Bluebird

Townsend's Solitaire

Veery

Gray-cheeked Thrush

Swainson's Thrush

Hermit Thrush

American Robin

Mimic Thrushes

Gray Catbird

Brown Thrasher

Pipits

Water Pipit

Sprague's Pipit
B Sp Su F W

$\mathrm{O}$ -

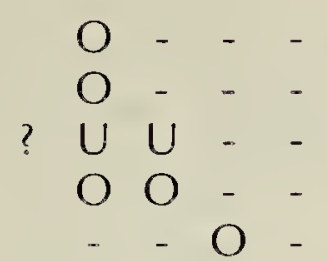

* $\overline{\mathrm{C}} \mathrm{C} \mathrm{U}-$

* C C U -

* C C C U

* UU - -

* C C U .

$\begin{array}{lllll} & - & - & \mathrm{O} & - \\ * & \mathrm{U} & \mathrm{U} & \mathrm{U} & - \\ * & \mathrm{U} & \mathrm{U} & - & - \\ * & \mathrm{C} & \mathrm{C} & \mathrm{C} & -\end{array}$

Accidental

$\begin{array}{lllll} & R & - & R & - \\ * & C & C & C & C \\ * & C & C & C & - \\ - & - & O & O\end{array}$

$U-U U$

$R$ - R -

$R$ - $R$ -

$\mathrm{O}-\mathrm{C}^{-}$

* C C C -

* U U - -

* C C U -

$$
\begin{aligned}
& U-U- \\
& U-U-
\end{aligned}
$$

$U-U$ -

Accidental

$\mathrm{U} \mathrm{O}$ -

$U-U-$

$U-U$ -

$U-U$ -

* C U C -

* U U U -

* C C U -

$U-U-$

* C C C -
Group Species

Waxwings

Bohemian Waxwing

Cedar Waxwing

Shrikes

Northern Shrike

Loggerhead Shrike

\section{Starlings}

\section{Vireos}

European Starling

Solitary Vireo

Warbling Vireo

Red-eyed Vireo

Wood-Warblers

Tennessee Warbler

Orange-crowned

Warbler

Yellow Warbler

Magnolia Warbler

Cape May Warbler

Yellow-rumped Warbler

Palm Warbler

Bay-breasted Warbler

Blackpoll Warbler

Black-and-white Warbler

American Redstart

Ovenbird

Northern Waterthrush

Connecticut Warbler

Mourning Warbler

Common Yellowthroat

Wilson's Warbler

Canada Warbler

Tanagers

Western Tanager

Grosbeaks and Allies

Rose-breasted Grosbeak

Dickcissel

Sparrows and Allies

Rufous-sided Towhee

American Tree Sparrow

Chipping Sparrow

Clay-colored Sparrow

Vesper Sparrow

Lark Sparrow

Lark Bunting

Savannah Sparrow

Baird's Sparrow

Grasshopper Sparrow

Le Conte's Sparrow

Sharp-tailed Sparrow

Fox Sparrow

Song Sparrow

Lincoln's Sparrow

Swamp Sparrow

White-throated Sparrow

White-crowned Sparrow
B Sp Su F W

* $U-U-U R$

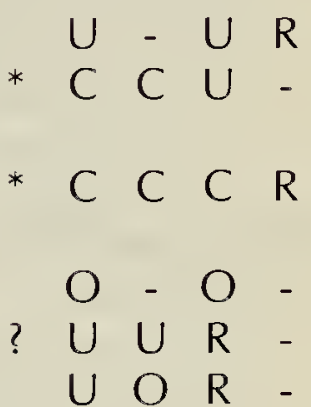

U R U -

$U-U$ -

* C C C -

$\mathrm{O}-\mathrm{O}$ -

$-\quad-R$ -

$C-C$ -

$U-C$ -

$\mathrm{O}-\mathrm{C}^{-}$

$U-U$

$R-R$

$U-U$ -

$R$ - R -

$\mathrm{O}-\mathrm{O}-$

$\mathrm{O}-\mathrm{O}^{-}$

$-\mathrm{O}^{-}$

U U U -

- $-U$ -

$-\quad \mathrm{R}-$

$-\quad \mathrm{O}$

$U-U$

- O O

$\mathrm{O}-$

$C-C$

C R U

* C C C

* C C U -

? $U \cup$ - -

* $\mathrm{OO}$ -

* C C C

* C C R

* R R R

* C C R

* U U R

$U-U$

* UUU.

U O U -

$U-U$ -

$C-C$

$C-C$ 


\begin{tabular}{|c|c|c|c|c|c|c|c|c|c|}
\hline Species & $B S p$ & & $F$ & W & Group $\quad$ Species & B Sp & Su & $F$ & $W$ \\
\hline Harris' Sparrow & U & - & C & - & Brown-headed Cowbird & $* \mathrm{C}$ & C & $U$ & - \\
\hline Dark-eyed Junco & C & - & C & - & Orchard Oriole & * $\mathrm{O}$ & $\mathrm{O}$ & - & - \\
\hline McCown's Longspur & $\mathrm{O}$ & $\mathrm{O}$ & - & - & Northern Oriole & * U & U & - & - \\
\hline Lapland Longspur & $A$ & - & A & - & Finches and Allies & & & & \\
\hline Smith's Longspur & - & - & $\mathrm{R}$ & - & Rosy Finch & - & 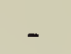 & - & $\mathrm{O}$ \\
\hline Chestnut-collared & & & & & Pine Grosbeak & & - & $\mathrm{O}$ & $\mathrm{O}$ \\
\hline Longspur & C & C & C & - & Purple Finch & $\mathrm{O}$ & - & $\mathrm{O}$ & - \\
\hline Snow Bunting & $U$ & - & $\mathrm{C}$ & $\mathrm{C}$ & White-winged Crossbill & 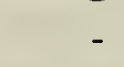 & $\mathrm{O}$ & $\mathrm{O}$ & - \\
\hline Blackbirds and Orioles & & & & & Common Redpoll & $\mathrm{U}$ & - & $\mathrm{U}$ & C \\
\hline Bobolink & $U$ & U & $U$ & - & Hoary Redpoll & - & - & - & $U$ \\
\hline Red-winged Blackbird & $\mathrm{C}$ & C & C & - & Pine Siskin & $U$ & $U$ & $\mathrm{U}$ & - \\
\hline Western Meadowlark & C & $\mathrm{C}$ & C & - & American Goldfinch & U & $U$ & $\mathrm{U}$ & \\
\hline Yellow-headed Blackbird & $\mathrm{C}$ & C & C & - & Evening Grosbeak & - & - & - & $\mathrm{O}$ \\
\hline Rusty Blackbird & $U$ & - & $U$ & - & Old World Sparrows & & & & \\
\hline Brewer's Blackbird & $\mathrm{C}$ & C & C & - & House Sparrow & * & C & C & C \\
\hline Common Grackle & $U$ & $U$ & U & - & & & & & \\
\hline
\end{tabular}

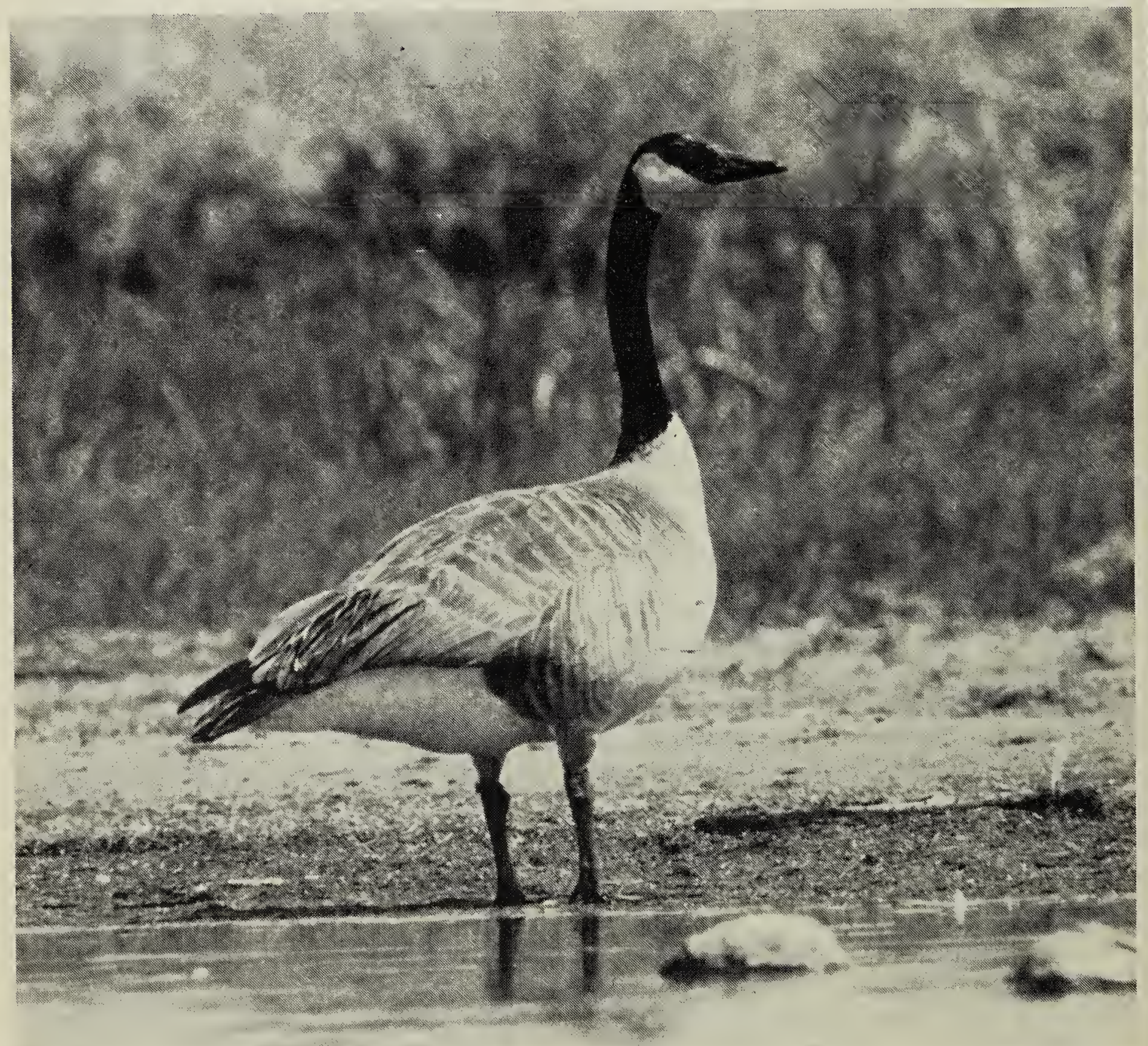

